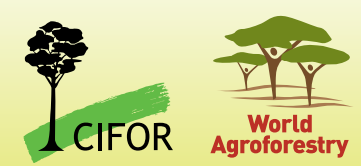

\title{
Lessons on social inclusion for transformative forest-based bioeconomy solutions
}

\author{
Juan Pablo Sarmiento Barletti, lliana Monterroso and Stibniati Atmadja
}

\section{Key messages}

- The transformational potential of bioeconomy solutions to advance environmental sustainability rests on whether they can deploy strategies for social sustainability.

- Bioeconomy can learn important lessons on social inclusion from previous research on redistribution, recognition, and representation concerns in forest-based climate initiatives.

- Initiatives should recognize Indigenous Peoples and local communities as right-holders in their design and implementation.

- They should ensure that enabling conditions are in place for women, youth and Indigenous Peoples and local communities to participate effectively throughout an initiative's lifetime.

- Initiatives should also provide mechanisms to promote a just and fair distribution of costs and benefits between stakeholders.

\section{Introduction}

Growing awareness of the climate crisis has led to calls for transformation: large-scale, sustainable shifts toward a climateresilient future (Atmadja et al. 2021). Forest-based bioeconomy solutions are one such transformational idea, defined broadly as "the utilisation of forests to create products and services that help economies to replace fossil-based raw materials, products and services" (Wolfslehner et al. 2016: 5). Such solutions draw heavily on innovations in biomass production and processing involving trees, forestry, and agroforestry. With regard to climate action, they could provide a decarbonization option for the global economy, as well as an opportunity to find common ground on production, land use, and emissions goals (Rodríguez et al. 2019). The bioeconomy approach takes into account risk-taking, innovation, and cross-sectoral collaboration that can help ensure large-scale adoption (Atmadja et al. 2021)

Bioeconomy solutions are fundamentally a strategy to increase use and re-use of renewable resources in economic processes. In the Global North, the European Commission adopted Europe's initial Bioeconomy strategy in 2012 (revised in 2018), and Bioeconomy Facilities are being promoted throughout the European Union. At the national level, Finland's Bioeconomy Strategy has set ambitious targets to create jobs and innovative products and services (Suomala 2019). In the Global South, Brazil has been a frontrunner on bioeconomy policies, including relevant legislation and the National Plan for Promoting the Chains of Products from Socio-biodiversity. Likewise, a recent review shows policy efforts in Sub-Saharan African to develop and promote bioeconomy solutions (Rosa and Martius 2021).

While bioeconomy solutions can be transformational - in terms of achieving the scale and speed needed - proponents have yet to take into account some of the more structural issues that need to be addressed to advance towards sustainability (Székács 2017; D'Amato et al. 2019), particularly the risks that could emerge if social sustainability concerns are not addressed (Rosa and Martius 2021). Consequently, it is not yet clear whether bioeconomy solutions will enable (or even protect) the rights and social inclusion concerns of the Indigenous Peoples and local communities that are the stewards of the forests targeted by bioeconomy applications (Diaz-Chavez et al. 2019). As the evidence from past initiatives demonstrates, an overriding emphasis on technical and economic factors takes for granted that social impacts will be beneficial and ignores potential trade-offs (Busher et al. 2017; Kothari 2021). Ample evidence demonstrates what can happen when forest-based initiatives neglect social inclusion concerns and fail to analyze their footprint on the wellbeing of the women and men of forest communities (Larson et al. 2021). Given that 1.6 billion Indigenous Peoples and local communities live in and around forests (Newton et al. 2020), with different management responsibilities over territories that store almost 300,000 million metric tons of 
carbon (RRI 2018), their concerns (and rights) cannot be ignored. In addition, these forest communities are suffering many of the effects of climate change while having done little to contribute to the problem (Brockhaus et al. 2021; Djoudi et al. 2016).

In this brief we argue that, as with other global environmental initiatives (and development initiatives more generally), the transformational potential of bioeconomy strategies depends on social inclusion. Specifically, this means its proponents' understanding of, and attention to, the contexts of exclusion in which initiatives are introduced, as well as learning from the experience of similar, previous initiatives (Myers et al. 2020; Sarmiento Barletti et al. 2020).

\section{Social inclusion}

Broadly, social inclusion is 'the process of improving the terms of participation for people who are disadvantaged on the basis of age, sex, disability, race, ethnicity, origin, religion, or economic or other status, through enhanced opportunities, access to resources, voice and respect for rights' (UN 2016: 20). Often defined both as a goal and as process, social inclusion is a political and socio-cultural issue that cannot be addressed through technical procedures alone (Monterroso et al. forthcoming). Rather, efforts to enhance social inclusion must address barriers (e.g., inequitable conditions, social practices, institutional arrangements), that constrain an actor's ability to engage in decision making (Fraser 2009). Forestdependent communities in particular tend to face challenges to their participation in decision-making processes over issues that affect their lives and livelihoods (Larson et al. forthcoming). This reflects a wider tendency where despite even recognized rights, communities still face barriers to access or exercise them (Ribot and Peluso 2009).

Although exclusion and rights transgressions are not necessarily driven by development and conservation initiatives, the failure to address exclusion is likely to reinforce or exacerbate it (Sarmiento Barletti and Larson 2020). When forest-based initiatives have attempted to foster inclusion, they sometimes do so by addressing the symptoms of injustice rather than its structural causes (Larson et al. 2021).

Forest-based bioeconomy solutions may provide an opportunity to strengthen social inclusion by promoting spaces to address justice concerns at the local level. This would require strategies that are designed and implemented to ensure access to material and nonmaterial benefits and shift from engaging the men and women of forest-dependent communities as 'beneficiaries' to collaborating with them as partners and change-makers. To support social inclusion these strategies must enhance agency, ensure effective forms of representation, support recognition of and access to rights, advance social justice, and promote equality.

In what follows we discuss how social inclusion concerns could support the transformational potential of forest-based bioeconomy solutions. First, we consider four main ways in which bioeconomy solutions may be transformational, together with their potential dimensions of inequity (Atmadja et al. 2021).

Second, we explore the multiple dimensions of social inclusion through the lens of redistribution, recognition, and representation (see Fraser 2009). We use this approach to explore how relevant forest-based initiatives have addressed (or not) these concerns. Redistribution describes the unjust distribution of resources and entitlements (e.g., the costs and benefits of ecosystem services) between powerful and less-powerful actors. Recognition relates to the demands for recognition of (and respect for) the different identities of groups and people within groups (e.g., socio-cultural identities, gender, etc.) and the sociocultural domination of some actors over others. Representation refers to practices that determine how individuals and groups can participate in decisionmaking processes that affect their lives (e.g., an intervention in their territory). These three arenas are intertwined, deeply political, and informed through historical and multilevel structures of injustice, and together help problematize the economic, socio-cultural, and governance structures that drive social exclusion. Finally, we conclude with lessons for inclusive bioeconomy solutions.

\section{Forest-based bioeconomy solutions and transformational change}

The transformational change potential of bioeconomy solutions is examined across four dimensions (Atmadja et al. 2021), as well as the challenges they might pose regarding the rights and justice concerns of forest-dependent communities in the Global South. Bioeconomy solutions may bring about:

1. Changing resource allocation, by proposing a shift of public and private financial, research, and policy support from (nonrenewable) fossil fuels into renewable forest-based substitutes. Such changes could include state subsidies to help households shift from diesel fuel to wood pellets for home heating, or support research and private investment in wood and bamboo products to replace single-use consumer plastics. With forest-based bioeconomy, land tenure and forest governance will determine who benefits from the reallocation of public and private resources. Most forested countries in the Global South have weak land tenure systems and forest governance, unlike the developed countries where the bioeconomy concept originated.

2. Changing processes, by focusing on changing consumption and production processes from linear (extract - produce - consume dispose) to circular.

Technical and financial innovations have been driving this process, such as creating markets for reuse/ recycling/ reconditioning services and up-stream design solutions for products to ensure their end-life circularity. These innovations have not clearly addressed the social issues of changing these processes, and whether those changes will improve or worsen inequities across peoples and places. For example, land 
scarcity for producing forestry materials in the Global North may move such production to the Global South. If the consumption and reuse/ recycling/ reconditioning processes take place in the North, this globally circular bioeconomy may lead to a linear depletion of biomass from one location to another. Effects on wellbeing are likely to be exacerbated in areas with weak land and forest tenure and governance.

3. Changing the legitimacy of public policy and discourses, from ensuring the wellbeing of the current generation at the expense of the future's, to ensuring the wellbeing of all generations including that of the future.

These discourses have not, however, been clear about whose future generation is being considered in light of the changes represented by the bioeconomy. The -largely technicalprocesses represented by the forest-based bioeconomy may favor the wellbeing of some (e.g., consumers in the Global North) at the expense of others (e.g., producers of raw materials in the Global South). This is especially serious where there are gender inequalities and barriers to rights recognition.

4. Changing the norms of development, by elevating the status of agriculture and forestry as a post-industrial rather than preindustrial solution.

This can have deep implications on how developing countries envision themselves in the future. Many low-income countries see an escape from their land-based economies towards industrialization as the key to achieving middle-income status. With its bioeconomy strategy, EU and many developed countries are disrupting that logic by proposing that moving in the opposite direction will lead to sustained high-income status. There is little analysis on the implications of this reversal for communities and smallholders in developing countries, and their access to participating in relevant decision-making processes.

\section{Lessons for social inclusion: redistribution, recognition, and representation}

This section summarizes lessons from research on other forestbased initiatives by examining redistribution, recognition and representation in relation to land tenure, gender and participation, respectively.

\section{Redistribution and land tenure}

Redistribution refers to the practices and structures that drive inequality, and the unequal distribution of resources and of the costs and benefits of initiatives, including entitlements and the ability to influence how distribution is decided. Acknowledging the lessons learned from REDD+ initiatives regarding the importance of clear land and resource tenure rights for communities is key to advancing initiatives promoting bioeconomy solutions in the Global South. Secure access to and control of land and resources is a key enabling factor for the potential of climate actions to make significant contributions to mitigation, adaptation, and the conservation of tropical forests, as it enables communities to influence decision-making and distribution mechanisms (Sunderlin et al. 2014; Monterroso and Sills 2022). Tenure interventions have been promoted widely to formalize community tenure rights through massive titling initiatives (Deininger et al. 2012; Monterroso and Sills 2022). Secure land tenure for Indigenous Peoples supports the effectiveness of climate change initiatives, as areas they occupy are more likely to be conserved than those that are not (Blackman et al. 2017; Schleicher et al. 2017). Nevertheless, formalization of rights has not granted Indigenous Peoples automatic use rights over forest resources, and in some cases key resources such as subsoil or carbon rights remain under state ownership; hence the redistribution process is incomplete (Monterroso et al. 2017). Two main challenges will affect the forest-dependent communities in which bioeconomy initiatives are implemented. First, on the ground, there is little acknowledgment that the forest landscapes where many climate change solutions are implemented are the traditional territories of Indigenous Peoples and local communities, despite the United Nations Declaration on the Rights of Indigenous Peoples (Larson et al. 2013; Monterroso et al. 2019). Second, even in countries with tenure reform interventions, legal frameworks tend to regulate rights to land, forests and carbon separately (Monterroso and Sills 2022). This not only results in legal overlaps and conflicts but also in formalization processes where Indigenous Peoples and other resource dependent people forfeit land, lose customary rights and accept new risks (Notess et al. 2020).

\section{Recognition and gender inequalities}

Recognition refers to the acknowledgement of diversity, and addresses structures and practices that influence how different forms of identity, interests, and knowledge are understood, valued and respected. There are multiple sources of differentiation, including gender, class, ethnicity, race, sexual identity, disability, and age. Bioeconomy solutions should specifically aim to identify and address the barriers that prevent less powerful groups from effective participation, and support equitable engagement with different knowledge systems. Approaching gender roles and relations in terms of recognition reveals how mainstream climate initiatives often fail to recognize and plan for engagement, neglecting to unpack how patterns of differentiation intersect and impact differently on individual and group identities (Bee and Basnett 2017). The failure to consider differences internal to forest-dependent communities, including power asymmetries along gender lines, may reproduce and reinforce the structures of inequality within them (Sarmiento Barletti et al. 2020). These asymmetries, built on socio-cultural practices and norms that constrain the effective participation of women and other marginalized groups, lead to differential access to decision-making in territorial governance (CIFOR and ONAMIAP 2020) and to the unequal distribution of benefits 
(Larson et al. 2018). These asymmetries are recognized in SDG 5 (on gender equality and women's empowerment) and can be explained by men's domination of both forest resources and decision-making spaces, both part of the public sphere, whereas women are more constrained to the private sphere of home and family (Bee and Basnett 2017). This constitutes a double bias: the gendered distinctions made by community members themselves and the gendered expectations of those implementing projects. As noted by the UNFCCC, women are more vulnerable to climate change, hence they need more than being present to legitimize an initiative (Djoudi et al. 2016). Considering gender as an add-on to initiatives or seeing the "gender problem" as one that can be solved by solving women's economic poverty create the risk of reinforcing or exacerbating women's experiences of exclusion. Emphasizing equity goals that address the intersecting dimensions of social differentiation, rather than a single lens (e.g., gender, poverty), is needed.

\section{Representation and participation}

Representation refers to issues of procedural justice, including the rules and practices that frame the access that groups (or individuals within groups) have to effective participation in different processes. This is an important consideration for bioeconomy solutions as different multi-stakeholder platforms and networks have been organized to develop bioeconomy actions, with little engagement with Indigenous Peoples and local communities. ${ }^{1}$ It is important to consider that social exclusions related to participation happen both inside communities and in their engagements with outsiders. Internally, there is evidence of women's exclusions from decisionmaking, as these tend to reproduce sociocultural norms that grant women unequal access to participation (Evans et al. 2021). These exclusions can exacerbate the already precarious positions held by women within their communities. Externally, it is accepted —at least discursively - that the participation of communities throughout the planning, implementation, and monitoring processes of initiatives in their territories is vital to their success and resilience over time (Sarmiento Barletti et al. 2020). This is also linked to Indigenous Peoples' recognized right-in International Labour Organization Covenant 169 and UNDRIP — to free, prior and informed consent regarding initiatives that affect their lives and territories. Generally, where participation has been recognized, it has commonly been applied only to implementation activities and not to the previous steps of the process (Saeed et al. 2017). Furthermore, there is also a growing interest in multi-stakeholder participatory platforms - bringing community representatives in collaboration with other actors - to collaborate towards better and more legitimate outcomes than those produced by top-down or unilateral decision-making processes (Sarmiento Barletti et al. 2020; Hewlett et al. 2021). However, despite the discursive inclusiveness of these platforms, they are challenged by the power inequalities

\footnotetext{
1 See https://europa.eu/regions-and-cities/programme/sessions/1505_en and http://www.eriaff.com/?page_id=890
}

inherent to the interactions between their participants (Londres et al. 2021; Palacios Llaque and Sarmiento Barletti 2021). Power inequalities are especially challenging for platforms organised to address unsustainable land and resource use in the Global South, in forest contexts framed by histories of inequality, conflict, and land dispossession (Gonzales et al. 2021). Unchecked power inequalities may limit the possibility of equitable collaboration among equals and may lead to agreements that benefit powerful actors, and that are legitimised by the participation of less powerful actors (Sarmiento Barletti and Larson 2019). There are also questions regarding the appropriateness of platforms as mechanisms to foster respect for the recognised rights of vulnerable peoples, and to promote a productive and equitable relationship between their rights and mainstream development interests (Rodriguez and Sarmiento Barletti 2021).

\section{Lessons for more inclusive forest- based bioeconomy solutions}

Research on forest-based initiatives in the Global South highlights the need for bioeconomy solutions to have strategies to support and enable the rights recognition and social inclusion concerns of Indigenous Peoples and local communities, with a special focus on the women in those groups.

To support transformational change, initiatives must:

1. Recognize Indigenous Peoples and local communities as right-holders in the design and implementation of bioeconomy solutions.

2. Ensure enabling conditions are in place for the meaningful participation of Indigenous Peoples and local communities - and women and youth in those groups - in all relevant decision making processes.

3. Provide clear mechanisms that allow for a just and fair distribution of costs and benefits stemming from bioeconomy applications.

CIFOR's research on social inclusion with forest-based climate initiatives led to the participatory development of a toolkit with materials for different stakeholders to assess the context where initiatives are to be introduced, and to monitor their participatory aspects over time. These tools, developed to support and enable social inclusion through adaptive and reflexive learning in different settings, are available on https://www.cifor.org/ toolboxes/tools-for-managing-landscapes-inclusively/

\section{Acknowledgments}

The authors would like to thank Anne M. Larson and Christopher Martius for their deep engagement and help in improving the clarity of our message. This work was supported by the Norwegian Agency for Development Cooperation; and the CGIAR Research Programs on Forest, Trees, and Agroforestry (FTA). This work has been carried out under the CGIAR GENDER Platform. 


\section{References}

Atmadja S, Martius C, Leonard S. and Sanz Sanchez MJ. 2021. Transformational change to reduce deforestation and climate change impacts: A review of definitions, concepts and drivers in scientific and grey literature. Rome, FAO.

Bee B and Basnett BS. 2017. Engendering social and environmental safeguards in REDD+: Lessons from feminist and development research. Third World Quarterly 38(4): 787-804.

Blackman A, Corral L, Santos Lima E and Asner GP. 2017. Titling indigenous communities protects forests in the Peruvian Amazon. Proceedings of the National Academy of Sciences 114 (16): 41234128.

Brockhaus M, Di Gregorio M, Djoudi H, Moeliono M, Pham TT and Wong GY. 2021. The forest frontier in the Global South: Climate change policies and the promise of development and equity. Ambio 1-18.

Büscher B, Fletcher R, Brockington D, Sandbrook C, Adams W, Campbell L, Corson C, Dressler W, Duffy R, Gray N, et al. 2017. Halfearth or whole earth? Radical ideas for conservation, and their implications. Oryx 51(3): 407-410.

CIFOR and ONAMIAP 2020. ¿Cómo vamos? Una herramienta para reflexionar sobre la participación de las mujeres indígenas u originarias en la gestión y gobernanza de sus territorios. Lima, CIFOR.

D'Amato D, Droste N, Winkler KJ and Toppinen A. 2019. Thinking green, circular or bio: Eliciting researchers' perspectives on a sustainable economy with Q Method. Journal of Cleaner Production 230: 460-476.

Deininger KW, Selod H and Burns A. 2012. The Land Governance Assessment Framework: Identifying and Monitoring Good Practice in the Land Sector. Washington, D.C, World Bank.

Diaz-Chavez R, Mortensen S and Wikman A. 2019. Bioeconomy: Tapping Natural and Human Resources to Achieve Sustainability. Stockholm, Stockholm Environment Institute.

Djoudi H, Locatelli B, Vaast C, Asher K, Brockhaus M, Basnett BS. 2016. Beyond dichotomies: Gender and intersecting inequalities in climate change studies. Ambio 45 (S3): 248-262.

Fraser N. 2009. Scales of Justice: Reimagining Political Space in a Globalizing World. New York, Columbia University Press.

Evans K, Monterroso I, Ommbogoh DB, Liswanti N, Tamara A, Mariño H, Sarmiento Barletti JP and Larson AM. 2021. Getting it right: A guide to improve inclusion in multi-stakeholder forums. Bogor, CIFOR. Gonzales J, Sarmiento Barletti JP, Larson AM, Barnes G and Tucker C. 2021. Can multi-stakeholder forums empower indigenous and local communities and promote forest conservation? Conservation Science \& Practice.

Hewlett C, Sarmiento Barletti JP, Larson AM, Heise Vigil N and Cisneros N. 2021. Intensity and embeddedness: Two dimensions of equity approaches in multi-stakeholder forums. CIFOR Occasional Paper 221.

Jodoin S. 2017. Forest Preservation in a Changing Climate: REDD+ and Indigenous and Community Rights in Indonesia and Tanzania. Cambridge, Cambridge University Press.

Kothari A. 2021. Half-Earth or whole-Earth? Green or transformative recovery? Where are the voices from the Global South? Oryx 55(2): 161-162.
Larson AM, Sarmiento Barletti JP and Heise N. Forthcoming 2022. A place at the table is not enough: Accountability for indigenous peoples and local communities in multistakeholder forums. World Development.

Larson AM, Mausch K, Bourne M, Luttrell C, Schoneveld G, Cronkleton P, Locatelli B, Catacutan D, Cerutti P, Chomba S, et al. 2021. Hot topics in governance for forests and trees: Towards a (just) transformative research agenda. Forest Policy and Economics 131

Larson AM, Brockhaus M, Sunderlin WD, Duchelle AE, Babon A, Dokken T, Pham TT, Resosudarmo IAP, Selaya G, Awono A, et al. 2013. Land Tenure and REDD+: The Good, the Bad and the Ugly. Global Environmental Change 23(3): 678-689.

Larson AM, Solis D, Duchelle AE, Atmadja S, Resosudarmo IAP, Dokken T and Komolasari M. 2018. Gender lessons for climate initiatives: A comparative study of REDD+ impacts on subjective wellbeing. World Development 108:86-102.

Londres M, Larson AM and Sarmiento Barletti JP. 2021. The costs of elite-oriented multi-stakeholder forums to address deforestation: the case of the Green Municipalities Program in the Brazilian Amazon. International Forestry Review 23(S1).

Monterroso and Sills, 2022. Interaction of conditional incentives for ecosystem conservation with tenure security: multiple roles for tenure interventions In Holland, M. Masuda, Y. Robinson, B. (Eds) Land Tenure Security and Sustainable Development. Palgrave Macmillan.

Monterroso I, Cronkleton P, Pinedo D and Larson AM. 2017. Reivindicación de Derechos Colectivos: Reformas de Tenencia de Tierras y Bosques En El Perú (1960-2016). Lima, CIFOR.

Monterroso I, Cronkleton P and Larson AM. 2019. Commons, indigenous rights, and governance. In Hudson B, Rosenbloom $J$ and Cole D, eds. Routledge Handbook of the Study of the Commons. New York, Routledge: 376-391.

Monterroso, I.; Evans, K.; Barletti, J.P.; Larson, A.M.H; Ombogoh, D.B.; Liswanti, N.; Tamara, A.; Mariño, H.; (Forthcoming). Social inclusion and Multi-stakeholder Forums: Addressing barriers to the inclusion of women and Indigenous Peoples in land and resource use MSF. CIFOR.

Myers R, Rutt RL, McDermott C, Maryudi A, Acheampong E, Camargo M, Cam H. 2020. Imposing legality: hegemony and resistance under the EU Forest Law Enforcement, Governance, and Trade (FLEGT) initiative. Journal of Political Ecology 27(1): 126-146.

Newton P, Kinzer AT, Miller DC, Oldekop JA and Agrawal A. 2020. The Number and Spatial Distribution of Forest-Proximate People Globally. One Earth 3(3): 363-370.

Notess L, Veit P, Monterroso I, Sulle E, Larson AM, Gindroz A-S, Quaedvlieg J and Williams A. 2020. Community land formalization and company land acquisition procedures: A review of 33 procedures in 15 countries. Land Use Policy 104461.

Palacios Llaque D and Sarmiento Barletti JP. 2021. The challenges of multiple governmentalities and forms of participation in protected natural areas: The Amarakaeri Communal Reserve (Peruvian Amazon). International Forestry Review 23(S1). 
Ribot J and Peluso N. 2009. A Theory of Access. Rural Sociology 68(2): 153-181.

Rodriguez D and Sarmiento Barletti JP. 2021. Can multistakeholder forums mediate indigenous rights and development priorities? Insights from the Peruvian Amazon. International Forestry Review 23(S1).

Rodríguez AG, Rodrigues M and Sotomayor O. 2019. Towards a Sustainable Bioeconomy in Latin America and the Caribbean: Elements for a Regional Vision. Santiago, ECLAC.

Rosa SFP and Martius C. 2021. Forest-based bioeconomy in subSaharan Africa: Looking at benefits, barriers and burdens from a social sustainability standpoint. CIFOR Occasional Paper 219.

[RRI] Rights and Resources Initiative. 2018. A global baseline of carbon storage in collective lands: Indigenous and local community contributions to climate change citigation. https:// rightsandresources.org/wp-content/uploads/2018/09/A-GlobalBaseline_RRI_Sept-2018.pdf.

Sarmiento Barletti JP and Larson AM. 2020. Environmental justice in the REDD+ frontier: Experiences from the Amazon and beyond. In Robbins N and Fraser B, eds. Landscapes of Inequity: The Quest for Environmental Justice in the Andes/Amazon Region. Lincoln, University of Nebraska Press.

Sarmiento Barletti JP and Larson AM. 2019. The role of multistakeholder forums in subnational jurisdictions: Framing literature review for in-depth field research. CIFOR Occasional Paper 194
Sarmiento Barletti JP, Larson AM, Hewlett C and Delgado D. 2020. Designing for engagement: A Realist Synthesis Review of how context affects the outcomes of multi-stakeholder forums on land use and/or land-use change. World Development, 127, 104753.

Saeed A-R, McDermott C and Boyd E. 2017. Are REDD+ community forest projects following the Principles for Collective Action, as proposed by Ostrom? International Journal of the Commons 11 (1): 572.

Schleicher J, Peres CA, Amano T, Llactayo W and Leader-Williams N. 2017. Conservation Performance of Different Conservation Governance Regimes in the Peruvian Amazon. Scientific Reports 7 (1): 11318.

Sunderlin WD, Larson AM, Duchelle AE, Resosudarmo IAP, Huynh TB, Awono A and Dokken T. 2014. How Are REDD+ proponents addressing tenure problems? Evidence from Brazil, Cameroon, Tanzania, Indonesia, and Vietnam. World Development 55: 37-52.

Székács A. 2017. Environmental and ecological aspects in the overall assessment of bioeconomy. Journal of Agricultural and Environmental Ethics 30(1): 153-170.

Wolfslehner B, Linser B, Pülzl H, Bastrup-Birk A, Camia A and Marchetti M. 2016. Forest bioeconomy - a new scope for sustainability indicators. European Forest Institute.

\begin{tabular}{|l|l|} 
CGIAR & This work has been carried out under the CGIAR GENDER Platform, which is grateful for the support of \\
CGIAR Trust Fund Contributors. www.cgiar.org/funders
\end{tabular}

\begin{tabular}{|c|c|c|}
\hline 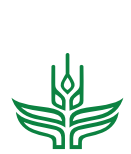 & $\begin{array}{l}\text { RESEARCH } \\
\text { PROGRAM ON } \\
\text { Forests, Trees and }\end{array}$ & $\begin{array}{l}\text { This research was carried out by CIFOR as part of the CGIAR Research Program on Forests, Trees and } \\
\text { Agroforestry (FTA). FTA is the world's largest research for development program to enhance the role } \\
\text { of forests, trees and agroforestry in sustainable development and food security and to address climate } \\
\text { change. CIFOR leads FTA in partnership with Bioversity International, CATIE, CIRAD, INBAR, ICRAF and TBI. }\end{array}$ \\
\hline CGIAR & & FTA's work is supported by the CGIAR Trust Fund: cgiar.org/funders/ \\
\hline
\end{tabular}

